\title{
Vascular Resections in Association With Pancreatic Resections for Locally Advanced Pancreatic Cancer
}

\author{
NICOLAE BACALBASA ${ }^{1,2}$, IRINA BALESCU ${ }^{3}$, ION BARBU ${ }^{1}$, OVIDIU STIRU ${ }^{4,5}$, \\ CORNEL SAVU $^{6,7}$, LUCIAN POP ${ }^{8}$, ADNAN AL ALOUL ${ }^{9}$, BOGDAN URSUT $^{10,11}$, \\ VLADISLAV BRASOVEANU ${ }^{1}$ and SORIN PETREA ${ }^{12}$ \\ ${ }^{1}$ Department of Visceral Surgery, Center of Excellence in Translational \\ Medicine "Fundeni" Clinical Institute, Bucharest, Romania; \\ ${ }^{2}$ Department of Obstetrics and Gynecology, \\ "Carol Davila" University of Medicine and Pharmacy, Bucharest, Romania; \\ ${ }^{3}$ Department of Surgery, "Ponderas" Academic Hospital, Bucharest, Romania; \\ ${ }^{4}$ Emergency Institute for Cardiovascular Diseases "Prof. Dr. C. C. Iliescu”, Bucharest, Romania; \\ ${ }^{5}$ Department of Cardiovascular Surgery, Carol Davila University of Medicine and Pharmacy, Bucharest, Romania; \\ ${ }^{6}$ Department of Thoracic Surgery, "Marius Nasta" National Institute of Pneumology, Bucharest, Romania; \\ ${ }^{7}$ Department of Thoracic Surgery, "Carol Davila" University of Medicine and Pharmacy, Bucharest, Romania; \\ ${ }^{8}$ Department of Obstetrics and Gynecology National Institute \\ of Mother and Child Care Alessandrescu-Rusescu, Bucharest, Romania; \\ ${ }^{9}$ Department of Surgery, Ramnicu Sarat County Hospital, Buzau, Romania; \\ ${ }^{10}$ Department of Surgery, "Carol Davila" University of Medicine and Pharmacy, Bucharest, Romania; \\ ${ }^{11}$ Department of Surgery, "Agrippa Ionescu” Clinical Emergency Hospital, Bucharest, Romania; \\ ${ }^{12}$ Department of Surgery, "Dr. I. Cantacuzino” Clinical Hospital, Bucharest, Romania
}

\begin{abstract}
Background/Aim: Locally advanced pancreatic cancer has been considered for a long period of time as an unresectable lesion and therefore, all patients have been traditionally addressed to the oncological services for palliative purposes. However, due to the wide usage of newer oncological agents in association with improved surgical techniques, radical surgical procedures became feasible. The aim of this study was to present the different surgical procedures that were performed in locally advanced pancreatic cancer patients in order to achieve radical resections. Patients and Methods: Between 2019 and 2020, six cases were submitted to pancreatic and vascular resections in Fundeni Clinical Hospital. Results: In all cases, surgery with curative intent was attempted; portal vein resection was performed in five cases, whereas arterial
\end{abstract}

This article is freely accessible online.

Correspondence to: Nicolae Bacalbasa, Carol Davila University of Medicine and Pharmacy, 37 Dionisie Lupu Street, 020021 Bucharest, Romania. Tel: +40 723540426, e-mail: nicolae_bacalbasa@yahoo.ro

Key Words: Vascular resection, locally advanced pancreatic cancer, borderline resectable pancreatic cancer, vascular reconstruction. resection was performed in three cases. Reconstruction was performed by direct re-anastomosis, by placing cadaveric or synthetic grafts. The postoperative outcomes were favourable in all cases. Conclusion: Vascular resections can be safely associated with pancreatic resections in cases presenting locally advanced pancreatic lesions, with acceptable morbidity rates.

Although the procedure of pancreatic head resection en bloc with duodenal resection has been suggested early during the nineteenth century, being proposed by Trendelenburg in 1882, Codvilla in 1898, Kausch in 1909, Hirschel in 1914 and Tenani in 1922, it has been standardised and defined by Allan Whipple in $1935(1,2)$. At that moment, the rates of intraoperative and postoperative complications were significant and therefore, certain surgeons considered that these procedures should be rather abandoned because the risks were higher than the benefits (3-5). During the following decades, improvement in the field of surgery and perioperative care leaded to a significant improvement in the long-term outcomes and encouraged surgeons worldwide to continue performing this procedure $(6,7)$. When it comes to vascular resections as part of the oncological abdominal surgical procedures, the first such resection was imagined by Appleby in 1953 and consisted of celiac axis resection in 
in vivo $36: 1001-1006(2022)$

Table I. Intraoperative details of the patients submitted to en bloc pancreatic and vascular resections.

\begin{tabular}{|c|c|c|c|c|c|c|}
\hline Case & Age & $\begin{array}{c}\text { CA15-3 } \\
\text { levels }\end{array}$ & $\begin{array}{l}\text { Preoperative } \\
\text { biopsy }\end{array}$ & $\begin{array}{l}\text { Vascular anatomical } \\
\text { particularities }\end{array}$ & $\begin{array}{l}\text { Type of } \\
\text { resection }\end{array}$ & $\begin{array}{c}\text { Type of } \\
\text { reconstruction }\end{array}$ \\
\hline 1 & 53 & 1,250 & $\begin{array}{c}\text { Well } \\
\text { differentiated } \\
\text { pancreatic } \\
\text { adenocarcinoma }\end{array}$ & $\begin{array}{l}\text { Right hepatic artery } \\
\text { originating from the superior } \\
\text { mesenteric artery. } \\
\text { Local invasion of the } \\
\text { mesenterico-portal confluent }\end{array}$ & $\begin{array}{l}\text { Total pancreatoduodenectomy } \\
\text { en bloc with splenectomy and } \\
\text { segmental resection of the } \\
\text { mesenterico-portal confluent } \\
\text { (Figure 1) }\end{array}$ & $\begin{array}{l}\text { Termino-terminal anastomosis } \\
\text { between the portal vein and } \\
\text { the superior mesenteric vein }\end{array}$ \\
\hline 2 & 57 & 580 & $\begin{array}{c}\text { Moderately } \\
\text { differentiated } \\
\text { pancreatic } \\
\text { adenocarcinoma }\end{array}$ & $\begin{array}{l}\text { Local invasion } \\
\text { of the portal vein }\end{array}$ & $\begin{array}{l}\text { Pancreatoduodenectomy } \\
\text { en bloc with the invaded } \\
\text { segment of the portal vein }\end{array}$ & $\begin{array}{c}\text { The portal vein was reconstructed } \\
\text { by local interposition } \\
\text { of a cadaveric venous graft } \\
\text { (Figure } 2 \text { and Figure } 3 \text { ) }\end{array}$ \\
\hline 3 & 59 & 960 & $\begin{array}{l}\text { Well differentiated } \\
\text { pancreatic } \\
\text { adenocarcinoma }\end{array}$ & $\begin{array}{l}\text { Local invasion } \\
\text { of the portal confluent } \\
\text { and of the superior } \\
\text { mesenteric vein }\end{array}$ & $\begin{array}{l}\text { Pancreatoduodenectomy en bloc } \\
\text { with the portal confluent and } \\
\text { superior mesenteric vein }\end{array}$ & $\begin{array}{l}\text { Synthetic Goretex graft } \\
\text { between the remaining } \\
\text { superior mesenteric vein } \\
\text { and the remaining } \\
\text { portal vein (Figure 4) }\end{array}$ \\
\hline 4 & 45 & 1,100 & $\begin{array}{c}\text { Poorly } \\
\text { differentiated } \\
\text { pancreatic } \\
\text { adenocarcinoma }\end{array}$ & $\begin{array}{l}\text { Local invasion of the right } \\
\text { hepatic artery. Right hepatic } \\
\text { artery originates from } \\
\text { the superior mesenteric artery }\end{array}$ & $\begin{array}{l}\text { Pancreatoduodenectomy en bloc } \\
\text { segmentary resection of the right } \\
\text { hepatic artery }\end{array}$ & $\begin{array}{l}\text { Termino-terminal } \\
\text { arterial anastomosis } \\
\quad(\text { Figure 5) }\end{array}$ \\
\hline 5 & 52 & 760 & $\begin{array}{c}\text { Poorly } \\
\text { differentiated } \\
\text { pancreatic } \\
\text { adenocarcinoma }\end{array}$ & $\begin{array}{l}\text { Local invasion of the portal } \\
\text { vein and superior } \\
\text { mesenteric artery }\end{array}$ & $\begin{array}{l}\text { Pancreatoduodenectomy en bloc } \\
\text { with portal vein and superior } \\
\text { mesenteric artery resection }\end{array}$ & $\begin{array}{l}\text { Termino-terminal porto-portal } \\
\text { anastomosis, reimplantation } \\
\text { of the superior mesenteric } \\
\text { artery in the abdominal aorta } \\
\text { (Figure } 6 \text { and Figure 7) }\end{array}$ \\
\hline 6 & 67 & 2,100 & $\begin{array}{c}\text { Poorly } \\
\text { differentiated } \\
\text { pancreatic } \\
\text { adenocarcinoma }\end{array}$ & $\begin{array}{l}\text { Local invasion of the portal } \\
\text { vein and of the common } \\
\text { hepatic artery }\end{array}$ & $\begin{array}{c}\text { Pancreatoduodenectomy en bloc } \\
\text { with common hepatic artery } \\
\text { and portal vein resection }\end{array}$ & $\begin{array}{l}\text { The portal vein was } \\
\text { reconstructed by placing } \\
\text { a cadaveric graft while the } \\
\text { common hepatic artery was } \\
\text { replaced by placing an arterial } \\
\text { cadaveric graft which was } \\
\text { anastomosed between the } \\
\text { remaining hepatic artery and } \\
\text { the celiac trunk (Figure } 8 \text { ) }\end{array}$ \\
\hline
\end{tabular}

locally advanced gastric cancer (8). Similar to the Whipple's procedure, the Appleby procedure was also deemed initially, as it was considered to have an unacceptable rate of perioperative complications (9). However, in time, due to the improvement of surgical techniques and of postoperative care, vascular resections have been widely associated as part of pancreatic resections in order to maximize the rates of radical resections (10-12). Moreover, in the last decade, these procedures have been also performed in a minimally invasive manner, increasing even more their efficacy (13-16).

\section{Patients and Methods}

After receiving the approval of the Ethical Committee from "Dan Setlacec" Center of Gastrointestinal Diseases and Liver Transplantation, Fundeni Clinical Institute no. 426/11.10.2021 data of patients submitted to synchronous pancreatic and vascular resections between 2019 and 2020 were reviewed and introduced in the current study. Six such cases were identified and their intraoperative and early postoperative outcomes are presented.

\section{Results}

The age of the patients included in the present study ranged between 45 and 67 years, the mean age being 55,5 years. The mean preoperative value of CA19-9 was $1,125 \mathrm{U} / \mathrm{ml}$ (ranging between 580 and 2,100 U/ml). All patients underwent preoperative computed tomography in order to exclude the presence of distant metastases, magnetic resonance imaging in order to assess the local extension of the lesion, as well as endoscopic ultrasound and biopsy. In all cases per primam surgical procedure was attempted; details regarding the presence of an arterial invasion were observed at the preoperative investigations in case 5, whereas in the remaining cases arterial involvement was observed intraoperatively. However, the decision to perform per primam resection in case 5 was taken after discussing the possible risks and benefits with the patient due to the overall good clinical and biological status. The intraoperative details are presented in Table I. 


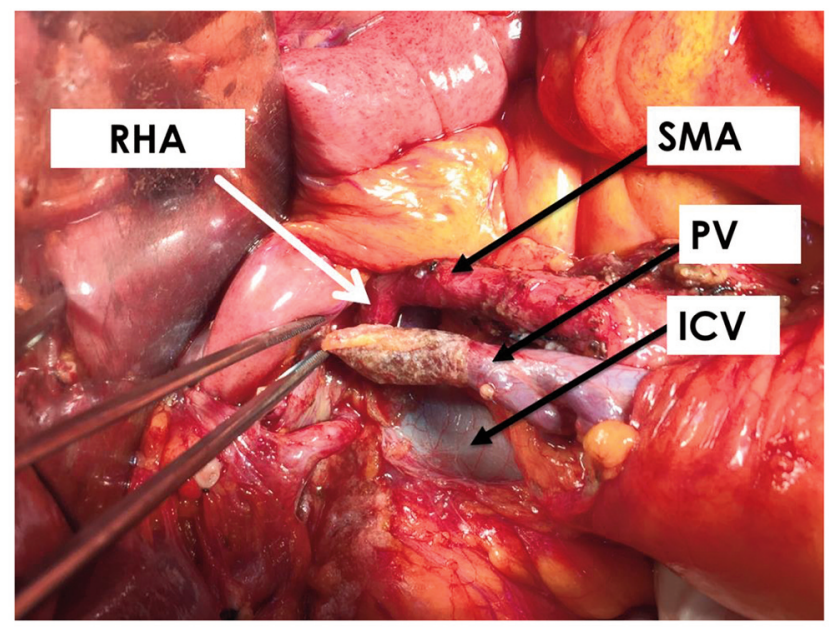

Figure 1. Total pancreatoduodenectomy en bloc with splenectomy and segmentary resection of the mesenterico-portal confluent. Direct anastomosis between the portal vein $(P V)$ and superior mesenteric vein was performed. Right hepatic artery (RHA) originating from the superior mesenteric artery (SMA). ICV: Inferior cava vein.

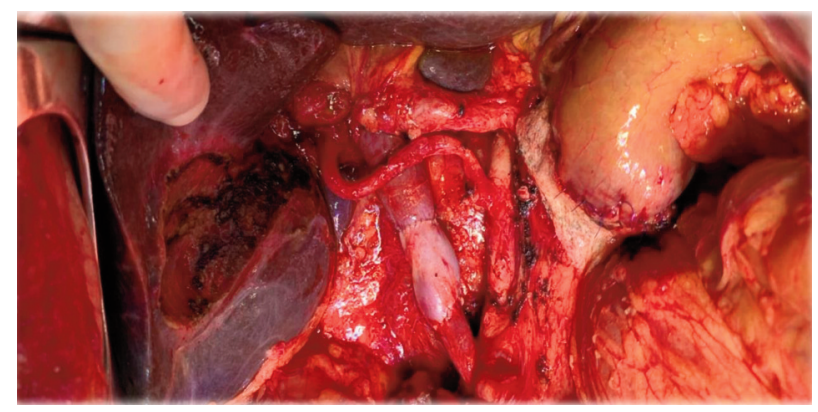

Figure 2. Pancreatoduodenectomy en bloc with the invaded segment of the portal vein. The portal vein was reconstructed by local interposition of a cadaveric venous graft.

In all cases radical resection was achieved, negative resection margins being achieved. Meanwhile, in all cases invasion of the resected vascular segments were demonstrated and the mean operative time was $420 \mathrm{~min}$ (range $=320-540$ min). The estimated blood loss ranged between $600 \mathrm{ml}$ and $1,500 \mathrm{ml}$, while the mean number of transfused units of erythrocytes was 3. Postoperatively, all patients were submitted to adjuvant chemotherapy. Computed tomography was performed in all cases in order to assess the functionality and patency of the vascular reconstructions and demonstrated the absence of local signs of vascular complications such as graft thrombosis. Intraoperative aspects are shown in Figure 1, Figure 2, Figure 3, Figure 4, Figure 5, Figure 6, Figure 7 and Figure 8.

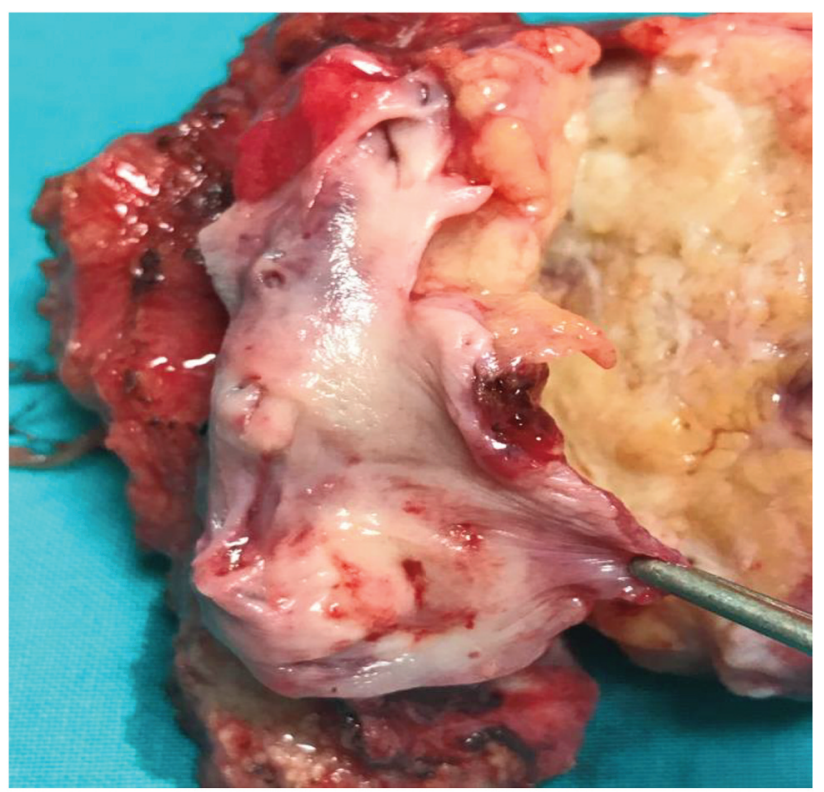

Figure 3. The specimen of pancreatoduodenectomy en bloc with the invaded segment of the portal vein.

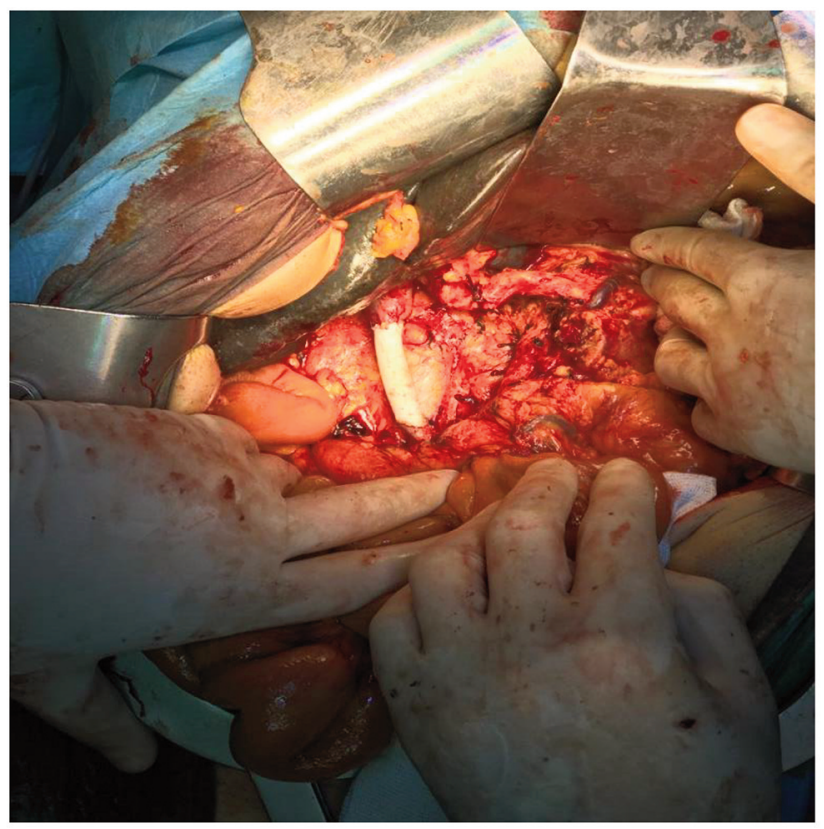

Figure 4. Pancreatoduodenectomy en bloc with the portal confluent and superior mesenteric vein. Synthetic Goretex graft between the remaining superior mesenteric vein and the remaining portal vein.

\section{Discussion}

The definition of unresectable pancreatic cancer has changed during the last decades. The initial step forward consisted of extending the limits of the definition of resectable pancreatic 




Figure 5. Pancreatoduodenectomy en bloc with segmentary resection of the right hepatic artery. The arterial continuity was re-established through a termino-terminal anastomosis.

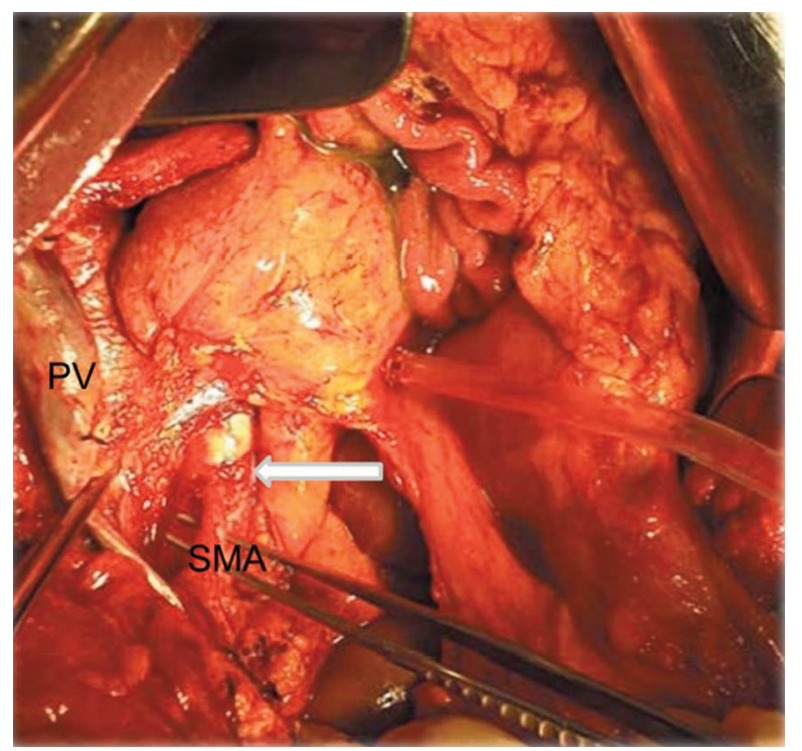

Figure 6. Termino-terminal porto-portal anastomosis and reimplantation of the superior mesenteric artery at the level of the abdominal aortathe final intraoperative aspect.

cancer to lesions presenting venous invasion. Therefore, at this moment it is strongly recognised that these lesions are considered as borderline resectable and therefore, cases presenting a good clinical and biological status are successfully submitted to venous resections en bloc with pancreatoduodenectomy (17-19). This was the first paradigm, which has been widely accepted in the last decades and the results in terms of survival did not fail to demonstrate the

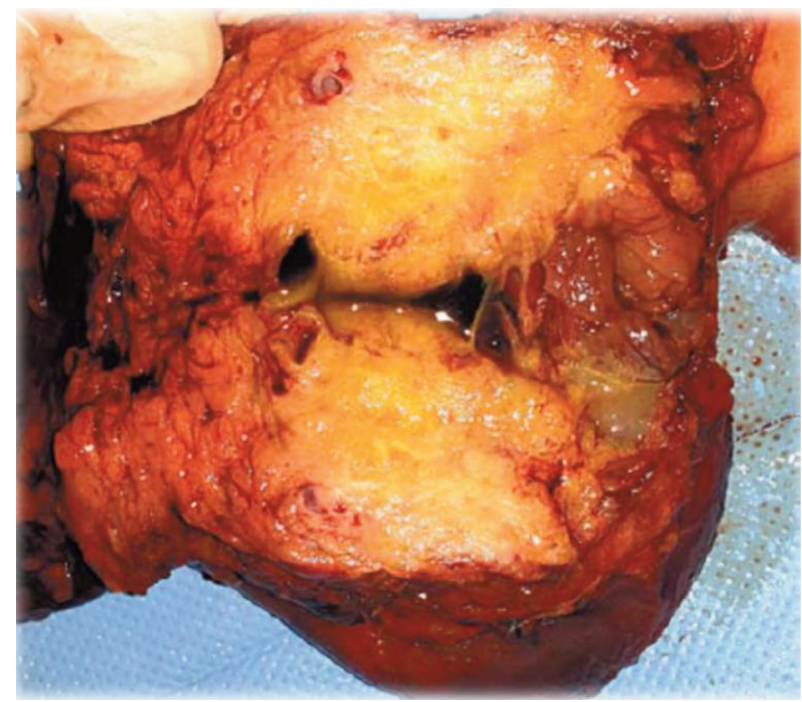

Figure 7. The specimen of pancreatoduodenectomy invading the portal vein and the superior mesenteric artery.



Figure 8. Pancreatoduodenectomy en bloc with portal vein and hepatic artery resection. Vascular reconstruction was performed by placing venous and respectively arterial cadaveric grafts.

effectiveness of these procedures; similar rates of long-term survival being reported in such cases when compared to cases submitted to standard pancreatoduodenectomy (17).

Once this fact was widely demonstrated and recognised, tertiary, high volume centres went further and tried to demonstrate whether cases presenting both arterial and venous invasion could also benefit from surgery as a first intention procedure (18). While in cases presenting exclusively venous invasion per primam resection is widely accepted nowadays, in cases presenting both arterial and venous invasions things are far from being well standardised $(18,19)$. Therefore, such cases presenting are currently classified as having locally advanced lesions and the therapeutic strategy differs depending on the 
general status of the patient and on the local conditions. Furthermore, in such cases, neoadjuvant chemotherapy could be proposed as first intention treatment, followed by re-evaluation through imaging, and in cases in which tumor regression is encountered, resection could be attempted (19-21). When talking about the type of pancreatic resection which should be performed in such cases, different opinions have been stated so far; while certain authors propose both cephalic pancreatoduodenectomy and total pancreatoduodenectomy, other tertiary centres propose routinely performing total pancreatoduodenectomy in order to diminish the risks of haemorrhagic, fatal complications. Therefore, in cases in which arterial resection is performed, leaving in place a pancreatic stump increases the risks of developing a postoperative pancreatic leak (22-26). In such cases, association between a pancreatic leak and an arterial anastomosis might induce the development of a fulminant arterial haemorrhage, which is fatal in most cases (27-29).

As for the types of vascular reconstructions, it has been widely demonstrated that depending on the local conditions, multiple types of reconstructions could be considered. Therefore, while in cases presenting limited invasion a parcelar resection followed by direct suturing or termino-terminal anastomosis could be performed, excluding in this way the possibility of placing a graft, in cases presenting more extended vascular invasion a graft is mandatory (30). While initially synthetic grafts such as Dacron or Goretex grafts have been proposed, nowadays cadaveric grafts represent the option of choice (31). In time, cadaveric grafts proved to be more efficient when compared to synthetic grafts due to the lower risks of thrombotic and infectious complications and therefore, there is a trend to replace them. However, it should not be omitted that cadaveric grafts or even autologous grafts are not always available, especially if cadaveric tissue banks are not available (32). Another interesting option that is associated with lower rates of postoperative complications is represented by animal grafts such as bovine pericardium. Similar to cadaveric or autologous grafts, bovine pericardium is associated with lower rates of postoperative complications such as thrombosis, but it is also more difficult to be obtained, prepared, and preserved and therefore, is not always available $(33,34)$.

\section{Conclusion}

Although initially the presence of vascular invasion has been considered for a long period of time as a sign of unresectable disease, and patients were submitted to palliative therapy, the therapeutic strategy has changed due to improvements in the field of perioperative and postoperative management. Therefore, both arterial and venous resections have been successfully performed as part of the therapeutic armamentarium of such cases. However, these procedures should be performed in tertiary centres, where the volumes of such cases are sufficiently larger, and thus significant experience has been obtained.

\section{Conflicts of Interest}

There are no conflicts of interest to declare regarding this study.

\section{Authors' Contributions}

VB, IoB, NB, OS, SP: performed the surgical procedures; NB, CS, $\mathrm{IrB}, \mathrm{OS}, \mathrm{AAA}, \mathrm{LP}$ reviewed literature data; $\mathrm{IoB}, \mathrm{BU}$ : preoperative investigation of the patient; IoB, NB, CS: prepared the draft of the manuscript; VB: was advisor of the surgical procedures; VB, NB: reviewed the final version of the manuscript. The Authors read and approved the final version of the manuscript.

\section{References}

1 Hirschel G: Die Resektion des Duodenums mit der Papille wegen Karzinoms. Munchen Med Wochenschr 61: 1728-1729, 1914.

2 Whipple AO, Parsons WB and Mullins CR: Treatment of carcinoma of the ampulla of Vater. Ann Surg 102(4): 763-779, 1935. PMID: 17856666. DOI: $10.1097 / 00000658-193510000-00023$

3 Gawande A: Two hundred years of surgery. N Engl J Med 366(18): 1716-1723, 2012. PMID: 22551130. DOI: 10.1056/ NEJMra1202392

4 DeBakey ME: A surgical perspective. Ann Surg 213(6): 499531, 1991. PMID: 2039282. DOI: 10.1097/00000658-199106 000-00001

5 Alexander JW: The contributions of infection control to a century of surgical progress. Ann Surg 201(4): 423-428, 1985. PMID: 3883923. DOI: 10.1097/00000658-198504000-00004

6 Giulianotti PC, Sbrana F, Bianco FM, Elli EF, Shah G, Addeo P, Caravaglios $G$ and Coratti A: Robot-assisted laparoscopic pancreatic surgery: single-surgeon experience. Surg Endosc 24(7): 1646-1657, 2010. PMID: 20063016. DOI: 10.1007/ s00464-009-0825-4

7 Dal Molin M, Zhang M, de Wilde RF, Ottenhof NA, Rezaee N, Wolfgang CL, Blackford A, Vogelstein B, Kinzler KW, Papadopoulos N, Hruban RH, Maitra A and Wood LD: Very long-term survival following resection for pancreatic cancer is not explained by commonly mutated genes: results of wholeexome sequencing analysis. Clin Cancer Res 21(8): 1944-1950, 2015. PMID: 25623214. DOI: 10.1158/1078-0432.CCR-14-2600

8 APPLEBY LH: The coeliac axis in the expansion of the operation for gastric carcinoma. Cancer 6(4): 704-707, 1953. PMID: 13059764. DOI: 10.1002/1097-0142(195307)6:4<704: :aid-cncr2820060410>3.0.co;2-p

9 Yamamoto Y, Sakamoto Y, Ban D, Shimada K, Esaki M, Nara S and Kosuge T: Is celiac axis resection justified for T4 pancreatic body cancer? Surgery 151(1): 61-69, 2012. PMID: 22088810. DOI: $10.1016 /$ j.surg.2011.06.030

10 Ham H, Kim SG, Kwon HJ, Ha H and Choi YY: Distal pancreatectomy with celiac axis resection for pancreatic body and tail cancer invading celiac axis. Ann Surg Treat Res 89(4): 167-175, 2015. PMID: 26446424. DOI: 10.4174/astr.2015.89.4.167

11 Baumgartner JM, Krasinskas A, Daouadi M, Zureikat A, Marsh W, Lee K, Bartlett D, Moser AJ and Zeh HJ 3rd: Distal pancreatectomy with en bloc celiac axis resection for locally advanced pancreatic adenocarcinoma following neoadjuvant therapy. J Gastrointest Surg 16(6): 1152-1159, 2012. PMID: 22399269. DOI: $10.1007 / \mathrm{s} 11605-012-1839-0$ 
12 Hirano S, Kondo S, Hara T, Ambo Y, Tanaka E, Shichinohe T, Suzuki O and Hazama K: Distal pancreatectomy with en bloc celiac axis resection for locally advanced pancreatic body cancer: long-term results. Ann Surg 246(1): 46-51, 2007. PMID: 17592290. DOI: 10.1097/01.sla.0000258608.52615.5a

13 Zureikat AH, Moser AJ, Boone BA, Bartlett DL, Zenati M and Zeh HJ 3rd: 250 robotic pancreatic resections: safety and feasibility. Ann Surg 258(4): 554-9; discussion 559-62, 2013. PMID: 24002300. DOI: 10.1097/SLA.0b013e3182a4e87c

14 Greer $\mathrm{J}$ and Zureikat AH: Robotic distal pancreatectomy combined with celiac axis resection. J Vis Surg 3: 145, 2017. PMID: 29302421. DOI: 10.21037/jovs.2017.08.18

15 Tseng JF, Raut CP, Lee JE, Pisters PW, Vauthey JN, Abdalla EK, Gomez HF, Sun CC, Crane CH, Wolff RA and Evans DB: Pancreaticoduodenectomy with vascular resection: margin status and survival duration. J Gastrointest Surg 8(8): 935-49; discussion 949-50, 2004. PMID: 15585381. DOI: 10.1016/ j.gassur.2004.09.046

16 Bacalbasa N, Balescu I, Tanase A, Brezean I, Vilcu M and Brasoveanu V: Successful resection of a non-functional paraganglioma with celiac trunk invasion followed by common hepatic artery reimplantation - a case report and literature review. In Vivo 32(4): 911-914, 2018. PMID: 29936479. DOI: 10.21873 /invivo. 11328

17 Hackert T, Ulrich A and Büchler MW: Borderline resectable pancreatic cancer. Cancer Lett 375(2): 231-237, 2016. PMID: 26970276. DOI: 10.1016/j.canlet.2016.02.039

18 Bockhorn M, Burdelski C, Bogoevski D, Sgourakis G, Yekebas EF and Izbicki JR: Arterial en bloc resection for pancreatic carcinoma. Br J Surg 98(1): 86-92, 2011. PMID: 21136564. DOI: $10.1002 /$ bjs.7270

19 Ferrone CR, Marchegiani G, Hong TS, Ryan DP, Deshpande V, McDonnell EI, Sabbatino F, Santos DD, Allen JN, Blaszkowsky LS, Clark JW, Faris JE, Goyal L, Kwak EL, Murphy JE, Ting DT, Wo JY, Zhu AX, Warshaw AL, Lillemoe KD and Fernándezdel Castillo C: Radiological and surgical implications of neoadjuvant treatment with FOLFIRINOX for locally advanced and borderline resectable pancreatic cancer. Ann Surg 261(1): 12-17, 2015. PMID: 25599322. DOI: 10.1097/SLA. 0000000000000867

20 Patel M, Hoffe S, Malafa M, Hodul P, Klapman J, Centeno B, Kim J, Helm J, Valone T and Springett G: Neoadjuvant GTX chemotherapy and IMRT-based chemoradiation for borderline resectable pancreatic cancer. J Surg Oncol 104(2): 155-161, 2011. PMID: 21520097. DOI: 10.1002/jso.21954

21 Hackert T, Ulrich A and Büchler MW: Can neoadjuvant therapy in pancreatic cancer increase the pool of patients eligible for pancreaticoduodenectomy? Adv Surg 51(1): 1-10, 2017. PMID: 28797331. DOI: 10.1016/j.yasu.2017.03.001

22 Stitzenberg KB, Watson JC, Roberts A, Kagan SA, Cohen SJ, Konski AA and Hoffman JP: Survival after pancreatectomy with major arterial resection and reconstruction. Ann Surg Oncol 15(5): 1399-1406, 2008. PMID: 18320285. DOI: 10.1245/ s10434-008-9844-y

23 Diener MK, Mihaljevic AL, Strobel O, Loos M, Schmidt T, Schneider M, Berchtold C, Mehrabi A, Müller-Stich BP, Jiang K, Neoptolemos JP, Hackert T, Miao Y and Büchler MW: Periarterial divestment in pancreatic cancer surgery. Surgery 169(5): 1019-1025, 2021. PMID: 33032819. DOI: 10.1016/ j.surg.2020.08.030
24 Schneider M, Strobel O, Hackert T and Büchler MW: Pancreatic resection for cancer-the Heidelberg technique. Langenbecks Arch Surg 404(8): 1017-1022, 2019. PMID: 31728630. DOI: 10.1007/s00423-019-01839-1

25 Del Chiaro M, Rangelova E, Halimi A, Ateeb Z, Scandavini C, Valente R, Segersvärd R, Arnelo $U$ and Verbeke CS: Pancreatectomy with arterial resection is superior to palliation in patients with borderline resectable or locally advanced pancreatic cancer. HPB (Oxford) 21(2): 219-225, 2019. PMID: 30093144. DOI: $10.1016 /$ j.hpb.2018.07.017

26 Hackert T, Sachsenmaier M, Hinz U, Schneider L, Michalski CW, Springfeld C, Strobel O, Jäger D, Ulrich A and Büchler MW: Locally advanced pancreatic cancer: Neoadjuvant therapy with folfirinox results in resectability in $60 \%$ of the patients. Ann Surg 264(3): 457-463, 2016. PMID: 27355262. DOI: 10.1097/SLA.0000000000001850

27 Hackert T, Werner J and Büchler MW: Postoperative pancreatic fistula. Surgeon 9(4): 211-217, 2011. PMID: 21672661. DOI: 10.1016/j.surge.2010.10.011

28 Isaji S, Mizuno S, Windsor JA, Bassi C, Fernández-Del Castillo C, Hackert T, Hayasaki A, Katz MHG, Kim SW, Kishiwada M, Kitagawa H, Michalski CW and Wolfgang CL: International consensus on definition and criteria of borderline resectable pancreatic ductal adenocarcinoma 2017. Pancreatology 18(1): 211, 2018. PMID: 29191513. DOI: 10.1016/j.pan.2017.11.011

29 Tzeng CW, Katz MH, Fleming JB, Lee JE, Pisters PW, Holmes HM, Varadhachary GR, Wolff RA, Abbruzzese JL, Vauthey JN and Aloia TA: Morbidity and mortality after pancreaticoduodenectomy in patients with borderline resectable type $\mathrm{C}$ clinical classification. J Gastrointest Surg 18(1): 146-55; discussion 155-6, 2014. PMID: 24129825. DOI: 10.1007/s11605-013-2371-6

30 Belfiori G, Fiorentini G, Tamburrino D, Partelli S, Pagnanelli M, Gasparini G, Castoldi R, Balzano G, Rubini C, Zamboni G, Crippa $\mathrm{S}$ and Falconi M: Vascular resection during pancreatectomy for pancreatic head cancer: A technical issue or a prognostic sign? Surgery 169(2): 403-410, 2021. PMID: 32912782. DOI: 10.1016/j.surg.2020.08.002

31 Stauffer JA, Dougherty MK, Kim GP and Nguyen JH: Interposition graft with polytetrafluoroethylene for mesenteric and portal vein reconstruction after pancreaticoduodenectomy. Br J Surg 96(3): 247-252, 2009. PMID: 19224515. DOI: 10.1002/bjs.6483

32 Kimura Y, Imamura M, Kuroda Y, Nagayama M, Itoh T, Oota S, Murakami T, Yamaguchi H, Nobuoka T, Kawaharada N and Takemasa I: Clinical usefulness of saphenous vein graft in major arterial reconstruction during extended pancreatectomy. Langenbecks Arch Surg 405(7): 1051-1059, 2020. PMID: 32737589. DOI: $10.1007 / \mathrm{s} 00423-020-01947-3$

33 Aryal B, Komokata T, Kadono J, Motodaka H, Ueno T, Furoi A and Imoto Y: First jejunal artery, an alternative graft for right hepatic artery reconstruction. World J Hepatol 7(4): 721-724, 2015. PMID: 25866610. DOI: 10.4254/wjh.v7.i4.721

34 Li PC, Thorat A, Jeng LB, Yang HR, Li ML, Yeh CC, Chen TH, Hsu SC and Poon KS: Successful application of supraceliac aortohepatic conduit using saphenous venous graft in right Lobe living donor liver transplantation. Liver Transpl 23(7): 976-980, 2017. PMID: 28073174. DOI: 10.1002/lt.24720

Received November 28, 2021

Revised December 14, 2021

Accepted December 15, 2021 